Volume 7 Issue 1, March 2020

Nationally Accredited Journal,

Decree No. B/4130/E5/E5.2.1/2019

\title{
The Legal Impact Of The Land Deed Official Whose Position Is Different From The Place Of Domicile As A Notary
}

\author{
Ardila Thaha ${ }^{1}$, Umar Ma'ruf ${ }^{2}$ and Widhi Handoko ${ }^{3}$
}

\begin{abstract}
The objectives of this study are: 1) To find out and explain the legal impact of the Land Deed Official whose position is different from the place of domicile as a Notary. 2) To find out the actions and steps that can be taken if in practice a Notary / PPAT gets a different position area. The method of approach used in this study is the Normative juridical approach. Retrieval of data with a library approach. The analysis was carried out qualitatively.

Based on the results of data analysis, it can be concluded that: 1) Notary who has been appointed in an office whose position is different from his area of office as a PPAT is temporarily dismissed from his position for violating the obligations and prohibition of office. Regulations regarding this matter are expressly regulated in UUJN. The person concerned is no longer entitled to make a deed, meaning that he no longer has the authority to make any deed, so if he turns out to still make a deed, then the deed concerned only has the power of proof as a deed under the hand. Whereas the PPAT who is appointed in a position whose position is different from his position as a Notary, causing the PPAT in question automatically stops automatically as a PPAT and for that reason, no dismissal decision is needed. Regulations regarding this matter are explicitly regulated in Government regulation number 24 of 2016 on Government regulation number 38 of 1998 on PPAT Position Regulations. 2) Notary / PPAT Actions and Steps that deal with the problems mentioned above must immediately submit an application to the relevant agency (DEPKUMHAM/BPM) to be able to adjust the area of office. In the event that the formation for the area concerned is closed, the relevant person must wait until the formation for the area is opened. In order to continue to carry out his position concerned must choose his work area as a Notary or work area as PPAT. Regulations regarding this matter are explicitly regulated in Government regulation number 24 of 2016 on Government regulation number 38 of 1998 on PPAT Position Regulations. Keywords: Legal Impact; Land Deed Official; Position; Notary.
\end{abstract}

\section{Introduction}

The history of Notary in Indonesia began at the beginning of the 17th century, precisely on August 27, 1620, Melchior Kerchem was appointed as the first Notary in Indonesia. The notary definition itself is contained in the provisions of Article 1 of Act No. 2 of 2014 on Amendments to Act No. 30 of 2004 on Notary Position Regulations (hereinafter referred to as UUJN), stating that Notaries are public officials who are authorized to make authentic deeds and authorities others as referred to in this Act. Generally the notary who was appointed was of European and eastern eastern descent because most indigenous communities did not get proper education. Nevertheless, there are still indigenous people who received education and were

\footnotetext{
${ }^{1}$ Student of Master of Notary Program Faculty of Law, Sultan Agung Islamic University (UNISSULA), Semarang, email: ardilathaha12@gmail.com

${ }^{2}$ Lecturer of Faculty of Notary Program, Faculty of Law, Sultan Agung Islamic University (UNISSULA), Semarang

${ }^{3}$ Public Notary / PPAT at Semarang City
} 
appointed as Notary Assistants. They are nobles or who have good relations with the colonial government. ${ }^{4}$

Article 2 of the UUJN states that a Notary is appointed and dismissed by the Minister. In article 1 number (14) of the UUJN Amendment meant by the Minister is the Minister who organizes government affairs in the field of law. The Minister in question is the Minister of Law and Human Rights. The appointment and dismissal of the Notary Public by the Minister began in 1945 with the enactment of Act No. 33 of 1945 on Deputy Notaries and Provisional Notaries. Previously, the appointment of Notaries was carried out by the Governor General (Head of State) based on Article 3 of the Reglement Op Het Notaris Ambt In Indonesia. ${ }^{5}$

Difference between Notary and Land Deed Forming Officer, hereinafter referred to as PPAT in terms of duties and authority, is to make an authentic deed regarding all deeds, agreements and provisions required by statutory regulations and / or desired by the interested parties to be stated in an authentic deed, guarantee certainty the date of making the deed, keeping the deed, giving the grosse, copy and quotation of the deed, all of it as long as the making of the deeds is not also assigned or excluded to other officials or others as determined by law.

PPAT in English is called land deed officials, while in Dutch it is called land titles registrar, has a very important position and role in the life of the nation and state because this official is given authority by the State, to make the deed of transfer of land and land titles. other deed in the Republic of Indonesia and abroad. ${ }^{6}$

PPAT has been known since the enactment of Government Regulation (hereinafter PP) Number 10 of 1961 on Land Registration, which is a land registration regulation as the implementation of Act No. 5 of 1960 On Basic Agrarian Regulations (UUPA). In the regulation, PPAT is stated as an official who functions to make a deed that intends to transfer land rights, give new rights or impose land rights. ${ }^{7}$

The PPAT function is further emphasized in Act No. 4 of 1996 on Mortgage Rights and Land Related Items and PP Number 24 of 1997 on Land Registration which replaces PP Number 10 of 1961, namely as a public official authorized to make deed of transfer of land rights, assignment of land rights, and other deeds regulated by applicable laws and regulations, and assist the Head of the Land Office in carrying out land registration by making deeds which will serve as the basis for registering changes in land registration data. ${ }^{8}$

The PPAT is appointed and dismissed by the Minister. The PPAT is appointed for a particular work area, to serve the public in making PPAT deeds in areas where there are not enough PPATs or to serve certain groups of people in making certain PPAT

\footnotetext{
${ }^{4}$ Ira Koesoemawati and Yunirman Rijan, 2009, Ke Notaris, Raih Asa Sukses, Jakarta, p. 27

${ }^{5}$ Sjaifurraachman and Habib Adjie, 2011, Aspek Pertanggunjawaban Notaris dalam Membuat Akta, Bandung, p. 67.

${ }^{6}$ Salim, HS., 2016 Teknik Pembuatan Akta Pejabat Pembuat Akta Tanah, Raja Grafindo Persada, Jakarta, p. 85

7Boedi Harsono, 2002, Hukum Agraria Indonesia, Himpunan Peraturan-Peraturan Hukum Tanah, Ed.rev., print. 19, (Jakarta: Djambat), p. 689.

${ }^{8}$ Ibid.
} 
Volume 7 Issue 1, March 2020

Nationally Accredited Journal,

Decree No. B/4130/E5/E5.2.1/2019

deeds, the Minister can appoint other officials as Provisional PPAT or Special PPAT. ${ }^{9}$

Based on the Government Regulation of the Republic of Indonesia Number 24 of 2016 on Amendment to Government Regulation Number 37 of 1998 on PPAT Position Regulations, it was stated that PPAT resigned from the position as PPAT because it carried out its duties as a Notary in a city / regency other than its working area as PPAT. Thus those who pass as PPAT and also have carried out their office duties as Notaries have different positions as PPAT, the PPAT concerned automatically stops as PPAT.

From the problems above, in this thesis, the writer will raise the title of the thesis "The Legal Impact Of The Land Deed Official Whose Position Is Different From The Place Of Domicile As A Notary".

\section{Research methods}

The method of approach used in this study is the normative juridical approach. An approach based on the main legal material by examining theories, concepts, principles of law and legislation related to this research. This approach is also known as the literature approach, namely by examining and analyzing legislation as primary legal material and studying books, other documents related to this research as secondary legal material, and looking at legal dictionaries and legal dictionaries as tertiary legal materials. . The analysis was carried out qualitatively.

\section{Results and Discussion}

\subsection{The Legal Impact Of The Land Deed Official Whose Position Is Different From The Place Of Domicile As A Notary}

Notary as a public official meaning to the Notary is given and equipped with public authority or authority on the public openbaar gezag. ${ }^{10}$ In providing public service (public service) in the field of word making services and other tasks that are charged to the notary public, which is attached to the title as a public official in the scope of the duties and authority of the Notary. ${ }^{11}$

Law of the Republic of Indonesia Number 2 of 2014 on Amendments to the Law of the Republic of Indonesia Number 30 of 2004 on Notary Position Article 17 paragraph (1) letter $g$ that "Notaries are prohibited from holding concurrent positions as Officials for Making Land Deed and / or Class II Auction Officers outside the domicile of the Notary and article 19 paragraph (2) which reads the domicile of the Notary as an Official for Deed of Land shall follow the domicile of the Notary ". And in Government

\footnotetext{
${ }^{9}$ Ngadino, 2019, Ketentuan Umum Tata Cara Pembuatan Dan Pengisian Akta PPAT, Universitas PGRI Semarang Press, Semarang, p. 38.

${ }^{10} \mathrm{R}$. Soegondo Notodisoerjo, 1993, Hukum Notariat di Indonesia Suatu Penjelasan, Raja Grafindo Persada, Jakarta, p. 44

${ }^{11}$ Paulus Efendi Lotulung, January 2003, Perlindungan Hukum Bagi Notaris, Papers for the Indonesian Notary Association Congress, Bandung.
} 
regulation number 24 of 2016 Regarding Changes to PP Number 37 of 1998 On PPAT Position Regulations clearly stipulates in article 9 paragraph (1) which reads:

But in real life or reality, sometimes things happen that we don't imagine that are different from the tori we get at university. One of them is regarding the granting of different positions for Notary and PPAT.

After the opening of the results of the Candidates for Land Drafting Candidates (PPAT) has created new problems, among them many participants who passed, who have also taken up positions as notaries, apparently there are different places of position (cities / districts) within their area of office (province) same or there are also different positions that are certainly different places of domicile.

Especially for those who pass as PPAT and apparently in different positions with Notary, for example as a Notary in one city / district in West Java Province, and graduating as PPAT in South Jakarta in DKI Jakarta, or graduating as a different PPAT city / district in the same position, for example graduating as a PPAT in Kediri City and as a Notary in Surabaya (both East Java Provinces) raises a very unique and funny problem, which only exists in Indonesia, especially in the world of Notaries and PPAT. To see this problem, we will place UUJN as a rule of law to solve it.

Whereas in Article 17 paragraph (1) letter $g$ of the UUJN, the Notary affirms that it is prohibited from holding concurrent positions outside the area of the Notary's position. If the prohibition is violated, based on Article 85 of the UUJN, administrative sanctions from the Notary Supervisory Board may be tiered first, given the opportunity to defend themselves starting from the MPD, MPW, MPP and in the end the MPP's proposal will be disqualified by the Minister of Law and HAM of the Republic of Indonesia.

Whereas later in Article 9 paragraph (1) letter $d$ of the UUJN, that the Notary was temporarily dismissed from his position for violating the obligations and prohibition of office. Therefore, a Notary with a different position area violates the Prohibition of the position as mentioned in Article 17 paragraph (1) letter $g$ of the UUJN, so the Notary concerned must be temporarily suspended from his position for 6 (six) months (Article 9 paragraph (4) UUJN). And before the dismissal is carried out to the concerned Notary was given the opportunity to defend themselves in stages before the Supervisory Council (Regional, Regional and Central) see Article (Article 9 paragraph (2) and (3) UUJN.

In another legal regulation, it is stated that based on Government Regulation of the Republic of Indonesia Number 24 of 2016 on Amendment to Government Regulation Number 37 of 1998 on PPAT Position Regulation, in Article 10 paragraph (4) letter d, it is confirmed that the PPAT is suspended as referred to in paragraph (1) letter c, because: appointed and took an oath of office or carry out his duties as a Notary with a domicile in a regency / city other than the domicile as PPAT. Thus those who pass as PPAT and also have carried out their duties as a Notary have different positions as PPAT, the PPAT concerned automatically stops temporarily as PPAT.

With the incident as mentioned above, so that any defense will be made by a Notary before the Supervisory Board or before the National Land Agency, there is no point because the mistakes are clear and the arrangements are clear, only in this case an 
incomplete understanding has occurred by colleagues notaries when they are going to take the PPAT candidates' exams, both against the UUJN and the Official Regulation on Land Drafting Officials regarding the area of office and position, in the sense that it is important to pass the PPAT exam.

The aforementioned provisions, due to the law order (UUJN) must be fully implemented by the Supervisory Council, if the Supervisory Council does not want to do it, then the Supervisory Council has violated the UUJN. Other problems will arise on the one hand the Supervisory Board will enforce the rule of law, on the other hand the Indonesian Notary Association (INI) as a Notary Public organization has the obligation to defend its members who experience such problems.

If it turns out that in reality, there are fellow Notaries and PPAT continue to carry out their duties as Notaries and PPAT even though it has clearly and clearly violated the provisions of Article 17 paragraph (1) letter $\mathrm{g}$ and Article 9 paragraph (1) letter $\mathrm{d}$ of the UUJN and Article 10 paragraph ( 4) letter d Government Regulation of the Republic of Indonesia Number 24 of 2016 on Amendment to Government Regulation Number 37 of 1998 On PPAT Position Regulations, are there any legal consequences to the deed and Notary / PPAT concerned? Such violations can be returned to the provisions of Article 1868 and 1869 of the Civil Code, which is deemed that the Notary / PPAT has carried out his office outside his authority, meaning that he no longer has the authority to make any deed, so that if he turns out to still make the deed, then the deed concerned only has the power of proof as a deed under the hand. To those parties who feel aggrieved from such Notary / PPAT actions, it is welcome to file a civil suit to the Notary / PPAT concerned, in the form of material and immaterial damages. If the Notary / PPAT concerned is unable to pay the compensation, the concerned Notary will be declared bankrupt, and the bankruptcy will ultimately be disrespectfully dismissed from his position as a Notary (Article 12 letter a UUJN). In the form of material compensation and immaterial. If the Notary / PPAT concerned is unable to pay the compensation, the concerned Notary will be declared bankrupt, and the bankruptcy will ultimately be disrespectfully dismissed from his position as a Notary (Article 12 letter a UUJN). In the form of material compensation and immaterial. If the Notary / PPAT concerned is unable to pay the compensation, the concerned Notary will be declared bankrupt, and the bankruptcy will ultimately be disrespectfully dismissed from his position as a Notary (Article 12 letter a UUJN).

\subsection{Actions and Steps That Can Be Taken If In Practice A Notary / PPAT Which Gets A Different Position}

The first steps and steps that can be taken if a Notary is appointed to be a PPAT with a different area is to be active in the BPN to immediately take care of changes or mutations in the work area requested, whether a decree has been issued or a decree has not yet been issued as a PPAT. The person concerned immediately to the Central BPN to propose changes in the working area to follow the Notary Work Area by attaching his Appointment Decree as Notary and Minutes of his Inauguration as 
Notary.

If it turns out that the requested working area is closed or there is no formation, then the concerned must wait until there is a formation / evaluation of the area. The problem is waiting here in the sense of not being able to determine how long and for how long. While waiting for certainty that can be done, the person concerned must make a choice, choose his work area as a Notary or his work area as PPAT, because as described above, a Notary / PPAT may not have a branch office / representative office and must have 1 (one) office domiciled in the working area and if the Notary doubles as a PPAT, the Notary office also becomes the PPAT office he doubles.

To the Notary / PPAT who experience problems as mentioned above, it is advisable not to make a Notarial Deed or the PPAT Deed in matters of different domiciles and positions. This is to avoid sanctions and claims for compensation from certain parties who feel disadvantaged because if it turns out that in reality, the Notary and PPAT continue to carry out their duties as Notaries and PPAT even though it has clearly and clearly violated the provisions of Article 17 letter $g$ and Article 9 paragraph (1) letter d UUJN and Article 8 aya (1) letter c Government Regulation of the Republic of Indonesia Number 37 of 1998 on PPAT Position, there are legal consequences to the deed and Notary / PPAT concerned.

To avoid sanctions and claims for compensation from certain parties as mentioned above, for the time being the Notary / PPAT concerned must choose one of them, carry out the position of Notary or PPAT. ${ }^{12}$

If the person concerned chooses his working area as a Notary, then the PPAT must move. However, in this case the provisions of Article 9 PP Number 37 of 1998 on PPAT are "PPAT who stop serving as PPAT because they are appointed and take the oath of office of a Notary in District / Municipality of the Second Level Region other than the work area may be re-appointed as PPAT with the working area Regency / Municipality Level II Region where the position is as a Notary, if the PPAT formation for the work area has not been fulfilled ".

In the explanation of article 9, it is emphasized, because the appointment of PPAT is associated with an area of land registration, the term "moving work area" is not known. To carry out tasks with other work areas a PPAT stops as a PPAT in one work area and then is reappointed as a PPAT for another work area. For this reappointment there is no need for the first appointment process, but it still has to take an oath of PPAT position before the Head of the Regency / Municipality Land Office in the new working area.

The relevant PPAT is required to submit the protocol to other PPAT in the old work area. Submission of this protocol is necessary so that the maintenance of the deeds of the deed can continue so that if needed at any time it can be found immediately.

\section{Closing}

12 "Dilema: Notary and PPAT with Different Position / Position Area," < http://hermannotary.blogspot.com/2009/06/dilemma-notaris-dan-ppat-yang-beda.html>,14 June 2009, downloaded on 2 February 2020. 
Volume 7 Issue 1, March 2020

Nationally Accredited Journal,

Decree No. B/4130/E5/E5.2.1/2019

\subsection{Conclusion}

- A notary who is appointed in an area of office whose position is different from the area of his position as a PPAT is suspended temporarily from his position (valid for a maximum of 6 (six) months) for violating the obligations and prohibition of office. The regulation regarding this matter is expressly regulated in article 9 paragraph 1 letter $d$ article 17 paragraph (1) letter $g$ UUJN. The person concerned is no longer entitled to make a deed, meaning that he no longer has the authority to make any deed, so if he turns out to still make a deed, then the deed concerned only has the power of proof as a deed under the hand. Whereas the PPAT who is appointed in a position whose position is different from his position as a Notary, causing the PPAT in question automatically stops automatically as a PPAT and for that reason, no dismissal decision is needed. The regulation regarding this matter is expressly regulated in article 10 paragraph (4) point d Government regulation number 24 of 2016 on government regulation number 38 of 1998 on PPAT Position Regulations.

- Actions and steps that can be taken if in practice a Notary / PPAT obtains a different position area must immediately submit an application to the relevant agency ( $D E P K U M H A M / B P M$ ) to be able to adjust its position area. In the event that the formation for the area concerned is closed, the relevant person must wait until the formation for the area is opened. In order to continue to carry out his position concerned must choose his work area as a Notary or work area as PPAT.

\subsection{Suggestion}

- Notary / PPAT to avoid sanctions and compensation claims from certain parties as mentioned above, temporarily choose one of them, carry out the position of the position of Notary or PPAT only.

- To the Notary / PPAT who have different occupation areas, they are advised not to make a Notarial Deed or PPAT Deed on the issue of the different domiciles and positions.

\section{References}

[1] Boedi Harsono. 2002. Hukum Agraria Indonesia, Himpunan Peraturan-Peraturan Hukum Tanah, Ed.rev., Print. 19, (Jakarta: Djambat).

[2] Ira Koesoemawati and Yunirman Rijan, 2009, Ke Notaris, Raih Asa Sukses, Jakarta.

[3] Ngadino. 2019. Ketentuan Umum Tata Cara Pembuatan Dan Pengisian Akta PPAT, PGRI University Semarang Press, Semarang.

[4] Paulus Efendi Lotulung, January 2003, Perlindungan Hukum Bagi Notaris, Makalah Dalam Rangka Kongres Ikatan Notaris Indonesia, Bandung.

[5] R. Soegondo Notodisoerjo, 1993, Hukum Notariat di Indonesia Suatu Penjelasan, Raja Grafindo Persada, Jakarta. 


\section{JURNAL AKTA}

eISSN : 2581-2114, pISSN: 2406-9426

[6] Salim, HS. 2016. Teknik Pembuatan Akta Pejabat Pembuat Akta Tanah, Raja Grafindo Persada, Jakarta.

[7] Sjaifurraachman and Habib Adjie. 2011. Aspek Pertanggunjawaban Notaris dalam Membuat Akta, CV. Mandar Maju, Bandung.

[8] Act No. 2 of 2014 on Amendment to Act No. 30 of 2004 on Notary Position.

[9] Government Regulation Number 24 of 2016 on Amendment to Government Regulation Number 37 of 1998 on Regulation of Position of Land Deed Official.

[10] Habib Adjie Dilema: Notary and PPAT with Different Position / Position Area <http://herman-notary.blogspot.com/2009/06/dilemma- notary- and-ppat-yangdiffer.html>, 14 June 2009. 